\title{
Development of advanced mutant lines of barley with higher mineral concentrations through radiation-induced mutagenesis in Perú
}

\section{Desarrollo de líneas mutantes avanzadas de cebada con mayores concentraciones de minerales a través de mutagénesis inducida por radiación en Perú}

\author{
Gomez, L. ${ }^{1 *}$; Aldaba, G. ${ }^{1}$; Ibañez, M. ${ }^{1}$; Aguilar, E. ${ }^{1}$ \\ *Corresponding author: luzgomez@lamolina.edu.pe
}

\begin{abstract}
In Peru it is very important to increase food quality and production in the rural areas where a high poverty and malnutrition problems are found. Mutation induction is used to improve well adapted cultivars, by upgrading one or two characteristics, while retaining all its original attributes. Hordeum vulgare mutant lines were developed from the cultivar UNALM 96, following irradiation at 200 and 300 Gray. Mutant lines were selected in the $M_{8}$ generation with higher agronomic performance and nutritive quality. They were adapted to the highlands with grain yield within the range of 5 , 100 and $8,731 \mathrm{~kg} / \mathrm{ha}$, over the value of the parental material $(4,246 \mathrm{~kg} / \mathrm{ha})$ and showed improved contents of $\mathrm{P}(131 \mathrm{mg} / \mathrm{g}$ dry weight-DW), Zn (66 mg/g DW), Mn (55 mg/g DW), Fe (57 mg/g DW) and Cu (63 $\mu \mathrm{g} / \mathrm{g} \mathrm{DW})$.
\end{abstract}

Keywords: barley, mutation, gamma irradiation, quality

\section{Resumen}

En Perú es muy importante aumentar la calidad de los alimentos y la producción en las zonas rurales donde se encuentran altos problemas de pobreza y malnutrición. La inducción de la mutación se utiliza para mejorar los cultivares bien adaptados, mediante la mejora de una o dos características, y conservando todos sus otros atributos. Las líneas mutantes de Hordeum vulgare se desarrollaron a partir del cultivar UNALM 96, después de la irradiación a 200 y 300 Gray. Las líneas mutantes se seleccionaron en la generación M8 con mayor rendimiento agronómico y calidad nutritiva. Se adaptaron a las tierras altas con un rendimiento de grano dentro del rango de 5, 100 y 8,731 kg/ha sobre el valor del material parental (4,246 kg/ha) y mostraron mejores contenidos de P (131 mg/g de peso seco-DW), Zn (66 mg/g DW), Mn (55 mg/g DW), Fe (57 mg/g DW) y Cu (63 $\mu \mathrm{g} / \mathrm{g}$ DW).

Palabras clave: cebada, mutación, irradiación gamma, calidad

\section{Introduction}

Agriculture in the high Andean region of Peru is done under adverse conditions, with frequent drought and frost and in impoverished soils and mostly oriented to auto subsistence production. Above 3000 masl, the rural population uses mostly potatoes, barley, wheat, quinoa, beans and peas as staple food, and at lower altitudes maize, amaranth, among other crops. Diets consumed in the highland usually contain various sources of dietary protein, among them a mixture of cereals (barley, wheat and maize) with native grains (quinoa and amaranth). This mixture has a high biological value because amino acids and other nutritive compounds are provided by cereals (Jood and Singh, 2001; McKevith, 2004; Mahesh et al., 2010).

Barley (Hordeum vulgare) is an important introduced food crop in the highlands, and $70 \%$ of barley are used for human consumption as pearled grains, flakes and flour (Gomez-Pando et al., 2005). It could be a main source of minerals for low income rural population because it is a staple food in the Peruvian Andean region. It has agronomic value because its adaptability to marginal soils and climates. It has nutritious and medicinal value because it contributes with carbohydrates $(\sim 80 \%)$, proteins (6.9 to $25.0 \%$ ), lipids $(0.99$ to $3.2 \%)$, minerals ( 2 to $4 \%$ ), fiber and other compounds to the diet (Kent, 1971; Newman and Mcguire, 1985; Ulrich, 2001). In terms of minerals, barley is a good source of potassium, magnesium and phosphorus, iron, sulfur, copper, zinc, manganese, chromium, selenium, iodine and molybdenum. It is considered an excellent source of vitamins B (Villacres, 1996) partly due to its content of soluble fiber (beta glucans), it protects the intestinal mucous membranes and reduces blood sugar levels (Fastnaught, 2002; Gordon, 2002; Finocchiaro et al., 2005).

National yield average of barley in Peru is relatively low, it is about $1,499.7 \mathrm{~kg} / \mathrm{ha}$ (FAOSTAT, 2016). The production does not satisfy domestic demand so it is important to increase the quantity and quality of barley production in order to improve the nutrition and profitability of farmers in the Andean region. 
There are various plant breeding tools for obtaining increased productivity and quality, e.g., mutation induction. Mutation breeding has been used for improving various crops (Micke, 1998; Jain et al., 1998; Jamil and Khan, 2002; Muthusamy et al., 2003; Chopra, 2005; Gnanamurthy et al., 2012; Kurowska et al., 2012; Mehlo et al., 2013; Tshilenge-Lukanda et al., 2013; Oladosu et al., 2016, Raina et al., 2016, Gozukirmizi and Karlik, 2017). Mutations can improve agronomic traits and genetic quality while conserving valuable traits of existing varieties, including adaptation, quality, etc. Mutations are random and the values of the mutations depend on changes in the morphology and physiology of plants that impact the agronomic and quality performance. The present investigation was undertaken to induce useful mutations in barley using gamma irradiation.

The present investigation was undertaken to induce useful mutations in barley using gamma irradiation.

\section{Materials and Methods}

Genetic materials-The experimental material was the barley commercial cultivar UNALM96.

Management of mutant population-Barley dry seeds were gamma irradiated at doses of 200 and 300 Gray. Treated seeds of each dose along with an equal number of control (untreated) seeds were grown. All surviving plants were harvested individually to the $\mathrm{M}_{2}$ generation and radio sensitivity was evaluated through germination, seedling survival, stem length and root length. The $\mathrm{M}_{2}$ population was screened, the spectrum and frequency of mutations was established and chlorophyll mutations were identified using Gustaffson's classification (Gustaffson, 1947).

In the $M_{3}$ generation progeny, tests were conducted to determine the inheritance of changes or likely mutations in the $M_{2}$ generation. During the $M_{4}$ to $M_{8}$ generations, agronomic and quality characters were evaluated. Field control practices were based on standard managements for barley.

\section{Determination of quality traits -}

Determination of physical characteristics-Thousand kernel weight and test weight with the protocol of ICARDA (1988).

Determination of chemical characteristics - Grain protein content was made following the protocol of ASBC (1992).

Mineral grain content-Mg 24, P 131, S 34, K139, Zn 66, $\mathrm{Ca}$ 44, Mn 55, Fe 57 and Cu 63 was made by James Hutton Laboratories in the UK in Dundee, using ICP-MS - JAT technology.

Evaluation of agronomic traits-Yield ( $\mathrm{kg} / \mathrm{ha})$, life cycle (days), plant height $(\mathrm{cm})$ and disease response were recorded.
General descriptive statistics-For each characteristic, data matrix was constructed using Microsoft Office 2007. The analysis started with basic descriptive statistics: mean standard deviation (SD) and coefficient of variation (CV).

Selection of mutant lines for quantitative traits-To select the mutant lines, a range of theoretical values were established with values in most cases greater than or less than 10 - 20 percent from those mean values of the parental material. Yield trials were conducted using a randomized block design with three replications

\section{Results and Discussion}

Somatic effects - In the $\mathrm{M}_{1}$ generation, general reductions of germination, survival, length of seedlings height, length of seedlings root and fertility with the increment of the doses of gamma ray were observed. These somatic effects were reported in other crops with different treatments and mutagens (Ciftci et al., 2006; Albokari et al., 2012; Scaldaferro et al., 2013; Arisha et al., 2014).

Chlorophyll mutation - Genetic differences in chlorophyll mutation have been observed. In a population of 342 958 plants, several types of chlorophyll mutants were identified. In six row spike plants, there were albino $(0.09 \%)$, alboviridis $(0.0003 \%)$, striata $(1.7 \%)$, alboxantha $(0.0005 \%)$, xanthalba $(0.0011 \%)$, chlorine $(0.15 \%)$, lutescens $(0.005 \%)$, tigrina $(0,25 \%)$ and xantha $(0.03 \%)$. In two row spike plants, there were tigrina $(0,006 \%)$ and chlorine $(0.02 \%)$. In Figure 1 , some of these mutants are presented.

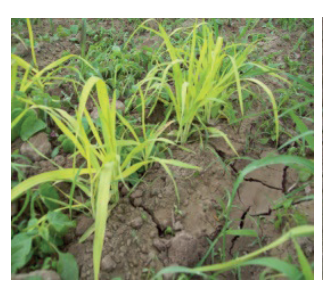

A

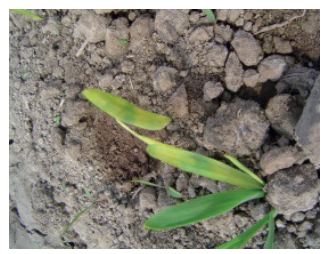

$\mathrm{C}$

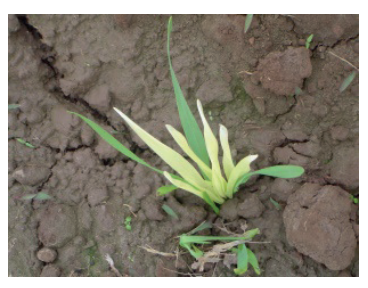

$\mathrm{B}$

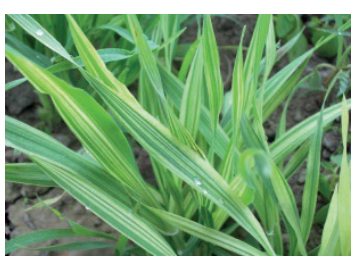

$\mathrm{D}$
Figure 1. Chlorophyll mutation types in barley cv UNALM 96 irradiated with $200 \mathrm{~Gy}$ of gamma ray at $\mathrm{M}_{2}$ generation (A: chlorine, B: albino, C: tigrina, D: striata). La MolinaPeru

Chlorophyll mutations are important markers for the evaluation of genetic effects of mutagenic treatments and have been reported in various crops (Gomez et al., 2009; Bhosale and Hallale, 2011; Ugorjiet al, 2012; Gnanamurthy 
et al., 2012; Tshilenge-Lukanda et al., 2013; Gomez-Pando and Eguiluz-de la Barra, 2013).

Morphological characteristics mutations-In the $M_{2}$ and following generations, a wide mutation spectrum was identified. The population that developed with the dose of 200 Gray was studied and the following modifications were found: stem color (1.68\%), auricle leaf color $(3.3 \%)$, spike morphology (4.78\%), awn color (2\%), awn -light curly $(0.43 \%)$, awnleted (5\%), elevated hood $(0.18 \%)$, sessile hood $(0.19 \%)$ and naked grain $(0.70 \%)$. Some of these spike morphology mutations are presented in Figure 2 .

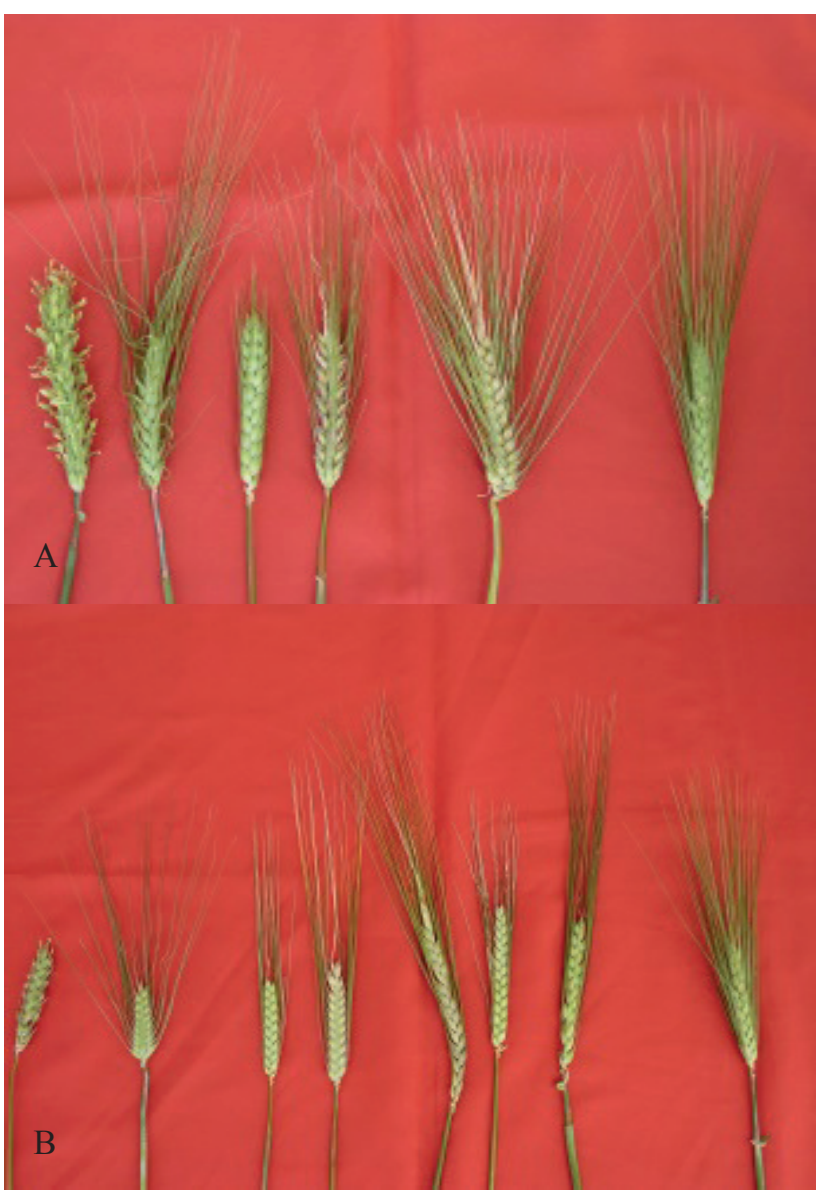

Figure 2. Spike morphology mutation types in barley cv UNALM 96 irradiated with 200 Gy of gamma ray at $\mathrm{M}_{2}$ generation (A:6 row with different types of awn, B:two row with different types of awn. La Molina- Peru

Morphological mutations were reported for barley and other crops (Gomez et al., 2009; Gnanamurthyet al., 2012; Dyulgerova, B. 2012; Jagajanantham et al., 2013). Some of the morphological mutations had economic importance such as naked grains. Barley is used at the highland roasted so naked grains are more easily processed.

Agronomic traits - In the $\mathrm{M}_{3}$ and following generations, plant height reduction $(2.12 \%)$ and earliness $(0.19 \%)$ were observed and the flowering periods were significantly reduced from 10 to 11 days compared to the control. Dockter and Hansson (2015) identified more than 1000 different short-culm barley mutants. In the $\mathrm{M}_{8}$ generation, 64 lines were selected with higher agronomic performances adapted to the highlands with grain yield within the range of $5100-8731 \mathrm{~kg} / \mathrm{ha}$, compared with the parental material with $4246 \mathrm{~kg} / \mathrm{ha}$ (Table 1).

Table 1.Grain yield of selected barley mutants of UNALM 96

\begin{tabular}{ll}
\hline Number of lines & Range of yield $(\mathrm{kg} / \mathrm{ha})$ \\
\hline 1 & 5250 \\
10 & $5125-7731$ \\
11 & $5100-6863$ \\
37 & $5131-8731$ \\
1 & 5294 \\
2 & $5106-5856$ \\
1 & 5675 \\
1 & 5550 \\
\hline & \\
\hline
\end{tabular}

Improvement of agronomic characteristics using gamma irradiation has been reported in barley and in other crops (Gustafsson et al., 1971; Khan et al., 2005; Gomez et al., 2009; Mudibu et al., 2010; Muthusamy et al., 2011; Kurowska et al., 2012; Ugorji et al., 2012; TshilengeLukanda et al., 2013; Gomez-Pando and Eguiluz-de la Barra, 2013; Udensiand Ntui, 2013; Gomez-Pando, 2014; Arisha et al., 2014; Badr et al., 2014, Obare et al., 2014).

Quality traits - Six hundreds and 65 advanced mutant lines in the $M_{8}$ generation from the variety UNALM 96, with different morphological and agronomic types of variation, were evaluated for their grain carbohydrate content and chemical characteristics, e.g., protein and mineral contents. Increase and decrease in all the characteristics evaluated were observed in the lines relative to the parental material. Almost all evaluated traits were improved and lines were selected with values of more than $20 \%$ over parentalal UNALM 96. For physical grain traits, 12 mutant lines were identified with improved thousand kernel weight within the range of 70.2 and $78.9 \mathrm{~g}$ which was greater than the value of parental material (56 g). For protein content, 21 mutant lines were identified within the range of 12.9 to $14.1 \%$; the parental material had $10.5 \%$ protein content. For mineral components, we identified many mutant lines. For Mg24, 50 mutants within the range of 1.44 to $4.04 \mathrm{mg} / \mathrm{g} \mathrm{DW}$ were selected (parent material had $1.167 \mathrm{mg} / \mathrm{g}$ of $\mathrm{Mg} 24(\mathrm{mg} / \mathrm{g}$ DW)). For P131, 54 mutant lines ranging from 5.27 - 7.59 $\mathrm{mg} / \mathrm{g}$ DW were superior to the parent with $3.980 \mathrm{mg} / \mathrm{g} \mathrm{DW}$. For S34, 63 mutant lines ranging from $1.61-2.05 \mathrm{mg} / \mathrm{g}$ DW of S34 were superior to the parent with $1.28 \mathrm{mg} / \mathrm{g} \mathrm{DW}$.

For Zn66, 67 mutant lines were selected ranging from 0.0574 to $0.0649 \mathrm{mg} / \mathrm{g} \mathrm{DW}$, which was superior to the parent with $0.0466 \mathrm{mg} / \mathrm{g}$ DW. For Ca 44, 32 mutant lines 
were selected ranging from 0.3976 to $0.4855 \mathrm{mg} / \mathrm{g} \mathrm{DW}$, which was superior to the parent with $0.3258 \mathrm{mg} / \mathrm{g}$. For Mn 55, 67 mutant lines were selected ranging from 0.0193 $-0.0322 \mathrm{mg} / \mathrm{g}$ DW, more than the parent with $0.0158 \mathrm{mg} / \mathrm{g}$ DW. For Fe57, 16 mutant lines were selected ranging from $0.11-0.4761 \mathrm{mg} / \mathrm{g} \mathrm{DW}$, which is better than the parent with $0.0417 \mathrm{mg} / \mathrm{g}$ DW. For Cu63, 72 mutant lines were identified ranging from 0.0099 to $0.0210 \mu \mathrm{g} / \mathrm{g} \mathrm{DW}$, better than the parent with $0.0067 \mu \mathrm{g} / \mathrm{g}$ DW. Some mutant lines showed improved resistance to leaf rust, lodging and grain content of P-131 from 2.88 to $6.16 \mathrm{mg} / \mathrm{g}$ DW, Zn66 from 0.044 to $0.0586 \mathrm{mg} / \mathrm{g} \mathrm{DW}, \mathrm{Mn} 55$ from 0.0142 to 0.0382 $\mathrm{mg} / \mathrm{g}$ DW, Fe57 from 0.0436 to $0.1396 \mathrm{mg} / \mathrm{g} \mathrm{DW}$ and Cu63 from 0.0.006 to $0.0142 \mu \mathrm{g} / \mathrm{g}$ DW (Table 2).

Genetic variability for quality characters can be induced successfully through mutations. Similar results were reported for barley (Muthusamy et al., 2002; Gómez

also an indirect indicator of malt extract and a variety with malting quality must have a value $>66 \mathrm{~kg} / \mathrm{hl}$.

The parental material UNALM 96 had $10.5 \%$ protein content and a group of mutant lines with values over and below the value of the parental material were identified. Globally there is evidence of improvement in food and malting barley quality (Swanston et al., 2002; Tamm, 2003). The use of barley is determined mainly by the protein. From the point of view of the brewery, barley should have a high content of starch as a source of fermentable sugars and protein content between 10 and $12 \%$ for good enzymatic activity. From a nutritional standpoint, the barley must have a good carbohydrate and high protein content, and other nutrients such as minerals (Emebiri et al, 2003; Emebiri et al, 2004; Emebiri et al, 2005; Iqbalet al., 2007). Crops can be enriched with micronutrients using plant breeding and/ or transgenic strategies, because micronutrient enrichment traits exist within their genomes that can be modified for substantially increasing micronutrient levels without negatively impacting crop productivity (Welchand Graham, 2004). Gregorio et al. (2000), White and Broadley (2009) and Mulualem (2015) indicated that the increment of bioavailable mineral elements in food crops through plant breeding is one important way to contribute to the solution of mineral deficiencies in human population and that can be

et al., 2009; Dyulgerova, 2012; Mehlo et al., 2013; Gómez, 2014), quinoa (Gomez-Pando, 2014) and other crops (Mehlo et al., 2013; Muthusamy et al., 2002).

Weight of 1000 seeds $(\mathrm{g})$ and test weight $\left(\mathrm{kg} / \mathrm{hl}^{-1}\right)$ were improved and are related to the kernel plumpness that are associated with endosperm size and starch content. In general there were values of TKW over and below the value of the parental material $(56.8 \mathrm{~g})$. For this character, 12 lines with higher value were selected ( 65 to $78.9 \mathrm{~g}$ ). The mass of a thousand grains is a good indicator of quality of malting and feed barley; the amount of malt extract, is positively correlated with grain size (Madić et al., 2005; Madić et al., 2006). Significant breeding progress was observed for 1000-grain weight (Ferrio et al., 2004). This trait was enhanced in 106 spring barley accessions of Slovak and former Czechoslovakia (Žakóvá et al., 2006). Grain Test Weight is strongly related to the degree of grain quality (grain size, shape, amount of starch, etc.), the parental material had an average value of $66 \mathrm{~kg} / \mathrm{hl}$ and naked mutant lines with higher values for this characteristic were identified within the range of 71.1 to $80.3 \mathrm{~kg} / \mathrm{hl}$. It mainly depended on the degree of filling, and shape and grain moisture (Madić et al., 2005; Madić et al., 2006). It is combined with agronomic characteristics improvement also. Velu et al. (2012) and Velu et al. (2014) mentioned that is very important to consider the association between micronutrients and agronomic traits such as grain yield, plant height, grain size and quality traits.

\section{Conclusions}

The dose applied of 200 and 300 Gray induced genetic variability for several studied traits when compared to the parental material. In addition, high doses of gamma irradiation in barley (300 Gray) caused severe somatic effects. It was possible to identify improved or novel phenotypes that can be used as cultivars or exploited as source of desirable characters in conventional breeding programs of barley. These improved mutant lines are free of the regulatory restrictions imposed on genetically modified organism. In some advanced mutant lines the change was in one or two desired characters without changing the rest of the genotype.

\section{Acknowledgements}

The authors would like to thank the IAEA for providing 
funding for these Research Projects through IAEA's Coordinated Research Project (CRP) "Improving Nutritional Quality by Altering Concentrations of Enhancing Factors Using Induced Mutation and Biotechnology in Crops.

\section{References}

Albokari, M.M.A., S.M. Alzahrani, and A.S. Alsalman. 2012. Radio sensitivity of some local cultivars of wheat (Triticum aestivum L.) to gamma irradiation. Bangladesh Journal of Botany 41: 1-5.

Arisha, M.H., B.K. Liang, S.N. Muhammad Shah, Z.H. Gong, and D.W. Li. 2014. Kill curve analysis and response of first generation Capsicum annuum L. B12 cultivar to ethyl methane sulfonate. Genetics and Molecular Research 13: 10049-10061.

American Society of Brewing Chemists. 1992. Barley. American Society of Brewing Chemists, St. Paul, Minnesota. USA.

Badr, A., H.I. Sayed Ahmed, M. Hamouda, M. Halawa, and M. Elhiti. 2014. Variation in growth, yield and molecular genetic diversity of M2 plants of cowpea following exposure to gamma radiation. Life Science Journal 11: 10-19.

Bhosale, U.P., and B.V. Hallale. 2011. Gamma radiation induced mutations in black gram (Vigna mungo (L.) Hepper). Asian Journal of Plant Science and Research 1: $96-100$

Ciftci, C.Y., TÜrkan, A.D., Khawar, K.M., Atak, M. and Özcan, S. Use of gamma rays to induce mutations in four pea (Pisumsativum L.) cultivars. Turk. J. Biol., 30: 29-37. 2006.

Chopra, V.L., Mutagenesis: investigating the process and processing the outcome for crop improvement. Curr. Sci.; 89:353-359. 2005.

Dockter, C., Hansson M. Improving barley culm robustness for secured crop yield in a changing climate. Journal of Experimental Botany, Volume 66, Issue 12, 1 June 2015, Pages 3499-3509.

Dyulgerova, B. 2012. Genetic diversity among induced mutants of winter barley (Hordeum vulgare L.). Journal of Central European Agriculture, 2012, 13(2), p.262272

Emebiri, L., Moody, D., Panozzo, J., Chalmers, K., Kretschmer, J. and Ablett, G., Identification of QTLs associated with variations in grain protein concentration in two row barley. Aust. J. Agric. Res. 54:1211-1221, 2003.

Emebiri, L., Moody, D., Panozzo, J., Chalmers, K., Kretschmer, J. and Ablett, G., Identification of QTLs associated with variations in grain protein concentration in two row barley. Aust. J. Agric. Res. 54:1211-1221, 2004.

Emebiri, L., Moody, D., Rorsley, R., Panozzo, J. and Read, B., The genetic control of grain protein content variation in a doubled haploid derived from a cross between Australian and North American two-rowed barley lines. J. Cereal Sci. 41:107-114, 2005.

FAOSTAT (http://faostat3.fao.org ).2016

Fastnaught, C., Barley Reduces Cholestrerol- An Update on Clinical Trials and FDA Petition. In Proceedings of North American Barley Researchers Workshops, p 8. 2002.

Ferrio, J.P., Alonso, N., Voltas, J. and Araus, J. 2004. Estimating grain weight in archaeological cereal crops: A quantitative approach for comparison with current conditions. J. Arch. Sci. 31:1635-1642, 2004.

Finocchiaro, F., Cavallero, A., Ferrari, B., Gianinetti, A. and Stanca, A.M., Barley for development of functional foods to improve human health in the third millennium. Food Barley: Importance, Uses and Local Knowledge: 145 - 156. 2005.

Gabert, V.M., Jorgensen H., Brunsgaard, G.; Eggum B.O.; Jensen, J. 1996. The nutritional value of new high lysine barley varieties determined with rats and young pigs. Canadian Journal of Animal Science : 443450

Gnanamurthy, S., Mariyammal, S., Dhanavel, D. and Bharathi, T., Effect of gamma rays on yield and yield component characters R3 generation in cowpea (Vignaunguiculata(L.) Walp). Int. J. Res. Plant Sci. 2: 39-42. 2012.

Gomez- Pando, L., Romero- Loli, M., Jimenez, J., Eguiluz, A. and Zolla, G., BarleyGeneticImprovement and ResearchActivities at Universidad Nacional Agraria La Molina. Food Barley: Importance, Uses and Local Knowledge: 138 - 140, 2005.

Gómez, L., Eguiluz, A., Jiménez, J. and Falconí, J. and Heros E., Barley (Hordeunvulgare) and kiwicha (Amaranthuscaudatus) improvement by mutation induction in Peru. In: Shu, Q.Y. (ed.) Induced plant mutations in the genomics era. Food and Agriculture Organization of the United Nations, Rome, pp. 330332. 2009.

Gomez-Pando, L. and Eguiluz-de la Barra, A., Developing genetic variability of quinoa (Chenopodium quinoa Willd.) with gamma radiation for use in breeding programs. American Journal of Plant Sciences, 4: 349355. doi:10.4236/ajps.2013.42046. Published Online February 2013 (http://www.scirp.org/journal/ajps). 2013

Gomez-Pando, L., Development of improved varieties of native grains through radiation-induced mutagenesis. En: Mutagenesis: Exploring novel genes and pathways. Ed: N.B. Tomlekova, M.I. Kozgar, M.R. Wani. Wageningen Academic Publishers. 105-123. 2014.

Gordon, D.T., Barley as a human food and functional food. In Proceedings of North American Barley Researchers Workshops, p 8. 2002.

Gozukirmizi N. and Karlik E. 2017. Barley (Hordeum 
vulgare L.) Improvement Past, Present and Future. Brewing Technology. Chapter 3 Downloaded from: http://www.intechopen.com/books/brewingtechnology: 49-78

Gregorio, G.B., Senadhira, S., Htut, H. and Graham, D., Food and Nutrition Bulletin, vol. 21no.4: 386. 2000

Gustaffson, A., Mutation in Agricultural Plants. Hereditas, 33, 1-40. 1947.

Gustafsson, A., Hagberg, A., Persson, G. and Wikland, K., "Induced Mutation and Barley Improvement," Theor. Appl. Gen. 41, 239-248. http://dx.doi.org/10.1007/ BF00277792. 1971.

Hehgaard J.; Boisen S. 1980. High lysine proteins in hiproly barley breeding: Identification, nutritional significance and new screening methods. Hereditas 93: 311-320.

Iqbal, M., Navabi, A., Salmon, D., Yang, R. and Spaner, D., Simultaneous selection for early maturity, increased grain yield and elevated grain protein content in spring wheat. Plant Breeding 126:244- 250, 2007

ICARDA. Crop Quality Evaluation Methods and Guidelines and ASBC. 1992. Barley, En ASBC, ed. Methods of analysis of the American Society of Brewing Chemists, 8th ed. American Society of Brewing Chemists, St. Paul, Minnesota. USA. 1988.

Jagajanantham, N. Dhanavel, D. Gnanamurthy, S. and Pavadai, P., Induced on chemical mutagens in Bhendi, Abelmoschus esculentus L. moench. Int J Curr Sci, 5: 133-137. Research Article ISSN 2250-1770. 2013.

Jamil, M. and Khan, U., Study on genetic variation in yield components of wheat cultivar Bukhtwar-92 as induced by gamma radiation. Asian J. Plant Sci., 1: 579-580. 2002

Jain S.M., Ahloowalia B.S. and Veilleux, R.E., Somaclonal variation and induced mutation in crop improvement. Kluwer Academic Publishers: 12; p: 203-218. 1998.

Jood S., Singh M. 2001. Amino acid composition and biological evaluation of the protein quality of high lysine barley genotypes. Plant Foods Hum Nutr. 2001; 56(2):145-55.

Khan, M. R., Qureshi, A. S., Hussain, S. A. and Ibrahim, M., "Genetic Variability Induced by gamma irradiation and Its Modulation with Gibberellic Acid in M2 Generation of Chickpea (Cicer arietinum L.), Pakistan J. Bot.37,285-292. 2005.

Kent, N.L., Tecnología de Cereales. Editorial Acribia, Zaragosa, España, p 271. 1971.

Kurowska, M., Labocha-Pawłowska, A., Gnizda, D., Maluszynski, M. and Szarejko, I., Molecular analysis of point mutations in a barley genome exposed to MNU and gamma rays. Mut. Res. 738- 739: 52-70. 2012.

Madić, M., Paunović A. and Durović; D., Correlations and path coefficient analysis for yield and yield components in winter barley. Acta Agric. Serbica 10:3-
9. 2005

Madić, M., Paunović, A., Bohan, N. and Veljković. L., Grain yield of new malting barley cultivars in different agroecological conditions. Acta Agric. Serbica 11:2935, 2006.

McKevith B. 2004. Nutritional aspects of cereals. British Nutrition Foundation Nutrition Bulletin, 29, 111-142

Mahesh, G. Abu- Ghannam, N., Gallaghar, E. 2010. Barley for Brewing: Characteristic Changes during Malting, Brewing and Applications of its By-Products. Comprehensive Reviews in Food Science and Food Safety. Vol 9, Issue 3: 259-328.

Micke A., Genetic Improvement of grain legumes using induced mutation. An overview. In: improvement of Grain Legume Production using Induced mutations, IAEA, Vienna, p: 1 - 51. 1998.

Mehlo, L., Mbambo, Z., Bado, S., Lin, J., Moagi, S.M., Buthelezi, S., Stoychev, S. and Chikwamba, R., Induced protein polymorphisms and nutritional quality of gamma irradiation mutants of sorghum. Mut. Res.; 749:66-72. 2013.

Mulualem; T., Application of Bio-fortification through Plant Breeding to Improve the Value of Staple Crops. Biomedicine and Biotechnology, 2015, Vol. 3, No. 1, 11-19 Available online at http://pubs.sciepub. com $/ \mathrm{bb} / 3 / 1 / 3$ (C) Science and Education Publishing DOI:10.12691/bb-3-1-3. 2015

Mudibu, J., Nkongolo, K.K., Kalonji-Mbuyi, A. and Kizungu, R., Effect of Gamma Irradiation on MorphoAgronomic Characteristics of Soybeans (Glycine max L.), Amer. J. Plant Sci. 3, 2010,. 331-337. http://dx.doi. org/10.4236/ajps.2012.33039. 2010.

Muthusamy, A., Ramanathan, B. and Jayabalan, N. Effects of gamma rays on seed protein profiles of Gossypium hirsutum L. J. Biosci 13 87-93. 2002.

Muthusamy, A., Vasanth, K. and Jayabalan N., Response of physiological and biochemical components in Gossypiumhirsutum L. to mutagens. J. Nuclear Agric. Biol.32: 44-51. 2003.

Muthusamy, A., and Jayabalan, N., In vitro induction of mutation in cotton (Gossypium hirsutum L.) and isolation of mutants with improved yield and fiber characters. Acta Physiol. Plant. DOI 10.1007/s11738011-0718-8. 2011

Newman, C.W. and Mcguire, C.F., Nutritional quality of barley. In Barley.Agronomy.ASA/CSSA/SSSA. Madison, Wisconsin, USA. Monograph No. 26: 403439, 1985.

Obare, I.J., Kinyua, M.G., Kiplagat O.K. 2014. Effects of induced mutagenesis on Agronomic Traits in Barley ( Hordeum vulgare L). American Journal of Experimental agriculture 4 (12): 1536-1543

Oladosu, Y., Mohd, R., Abdullah, N., Hussin, G., Ramli, A., Rahim,A.R., Miah G.\& Usman M. 2015. Principle and application of plant mutagenesis in 
crop improvement: a review, Biotechnology \& Biotechnological Equipment. Vol 30:1, 1-16, http:// dx.doi.org/10.1080/13102818.2015.1087333

Raina, A., Laskar, R.A.; Khursheed, S., Amin, R., Tantray, Y.R., Parveen K., and KhanS. 2016. Role of Mutation Breeding in Crop Improvement- Past, Present and Future. Asian Research Journal of Agriculture 2(2): $X X-X X, 2016$; Article no.ARJA.29334

Swanston, J. and Ellis; R., Genetics and breeding of malt quality attributes. In: Slafer GA, Molina-Cano J, Savin R, Araus J, Romagosa I (eds) Barley Science: Recent Advances from Molecular Biology to Agronomy, New Views on the Origin of Cultivated Barley. The Haworth Press, Inc, New York, pp 85-102, 2002.

Tallberg, A. \& Eggum, and B.O. 1981. The nutritional value of high-lysine barley genotypes. Plant Foods for Human nutrition Vol 31, Issue 2, pp 151-161. https:// doi.org/10.1007/BF01094039

Tamm, U. The variation of agronomic characteristics of European malting barley varieties. Agron. Res. 1:99103, 2003.

Scaldaferro, M.A., Prina, A.R., Moscone, E.A. and Kwasniewska, J., Effects of ionizing radiation on Capsicum baccatum var. pendulum (Solanaceae). Appl. Rad. Iso. 79: 103-108. 2013

Tshilenge-Lukanda, L., Kalonji-Mbuyi, A., Nkongolo, K.K.C. and Kizungu, R.V., .Effect of gamma irradiation on morpho-agronomic characteristics of groundnut (ArachishypogaeaL.) AJPS; 4: 2186-2192. 2013.

Udensi, O. and Ntui, V.O., Evaluating the performance of amiprophos methyl and $\gamma$-irradiated seeds on growth and yield traits of pigeon pea. Int. J. Agric. Biol.15, 885-890. 2013

Udensi, O.U., Ntia, M.I. and Obianwa, C.U., Optimizing induced mutation technique for the improvement of agronomic traits in pigeon pea [Cajanuscajan (L.) Millsp.] Landraces. Com. Sci5, p: 267-278. 2014.

Ugorji,O.U.,Ikpeme,E.V.,Obu,J.A. andEkpenyong,E.D., Assessing the mutagenic effects of gamma irradiation on Cajanuscajan (L.) Huth and Vignaunguiculata (L.) Walp landraces using morphological markers. Com. Sci.3, 271-281. 2012.

Ullrich, S., Genetics and breeding of barley feed quality atrributes. In: Slafer GA, Molina- Cano J, Savin R, Araus J, Romagosa I (eds) Barley Science: Recent Advances from Molecular Biology to Agronomy of Yield and Quality. The Haworth Press, Inc, New York, 115-142, 2001

Villacres, E., La cebada: un cereal nutritivo. Instituto Nacional Autónomo de Investigaciones Agropecuarias. Estación Experimental Santa Catalina. Quito, p 90. 1996.

Velu, G., Singh, R.P., Huerta-Espino, J., Peña-Bautista, R.J., Arun, B., Mahendru-Singh, A., Yaqub Mujahid, M., Sohu, V.S., Mavi, G.S., Crossa, J., Alvarado,
G.,Joshi, A.K., Pfeiffer, W.H., 2012. Performance of biofortified spring wheat genotypesin target environments for grain zinc and iron concentrations. 2012.Field Crops Res. 137, 261e267.

Velu, G.,Ortiz-Monasterio, I.; Cakmak, I.; Hao, Y.; Singh, R.P., Biofortification strategies to increase grain zinc and iron concentrations in wheat.Journal of Cereal Science 59: 365-372. 2014

Welch, R.M. and Graham, R.D., Breeding for micronutrients in staple food crops from a human nutrition perspective. J. Exp. Bot., 55, 353-364, 2004.

White, P. J., and Broadley, M. R., Biofortification of crops with seven mineral elements often lacking in human diets - Iron, zinc, copper, calcium, magnesium, selenium and iodine. New Phytol. 182:49-84. 2009.

Žakóvá, M. and Benková, M., Characterization of spring barley accessions based on multivariate analysis. Comm. Biometry Crop Sci. 1:124-134, 2006. 